LAWRENCE LIVERMORE NATIONAL LABORATORY

\section{PROTEIN ADDUCTS OF THE PROSTATE CARCINOGEN PHIP IN CHILDREN}

K.H. Dingley

Feb $18^{\text {th }}, 2004$

Annual Report for U.S. Army Medical Research and Materiel Command, Fort Detrick, Maryland 21702-5012 


\section{Disclaimer}

This document was prepared as an account of work sponsored by an agency of the United States Government. Neither the United States Government nor the University of California nor any of their employees, makes any warranty, express or implied, or assumes any legal liability or responsibility for the accuracy, completeness, or usefulness of any information, apparatus, product, or process disclosed, or represents that its use would not infringe privately owned rights. Reference herein to any specific commercial product, process, or service by trade name, trademark, manufacturer, or otherwise, does not necessarily constitute or imply its endorsement, recommendation, or favoring by the United States Government or the University of California. The views and opinions of authors expressed herein do not necessarily state or reflect those of the United States Government or the University of California, and shall not be used for advertising or product endorsement purposes.

\section{Auspices Statement}

This work was performed under the auspices of the U.S. Department of Energy by University of California, Lawrence Livermore National Laboratory under Contract W-7405-Eng-48. 
$\mathrm{AD}$

(Leave blank)

\section{Award Number: DAMD17-03-1-0076}

TITLE: Protein Adducts of the Prostate Carcinogen PhIP in Children

PRINCIPAL INVESTIGATOR:

Karen H. Dingley, Ph.D.

CONTRACTING ORGANIZATION:

Lawrence Livermore National Laboratory, 7000 East Avenue, Livermore, CA 94550

REPORT DATE:

Feb 2004

TYPE OF REPORT:

Annual

PREPARED FOR: U.S. Army Medical Research and Materiel Command, Fort Detrick, Maryland 21702-5012

DISTRIBUTION STATEMENT: (Check one)

X Approved for public release; distribution unlimited

Distribution limited to U.S. Government agencies only; report contains proprietary information

The views, opinions and/or findings contained in this report are those of the author(s) and should not be construed as an official Department of the Army position, policy or decision unless so designated by other documentation. 


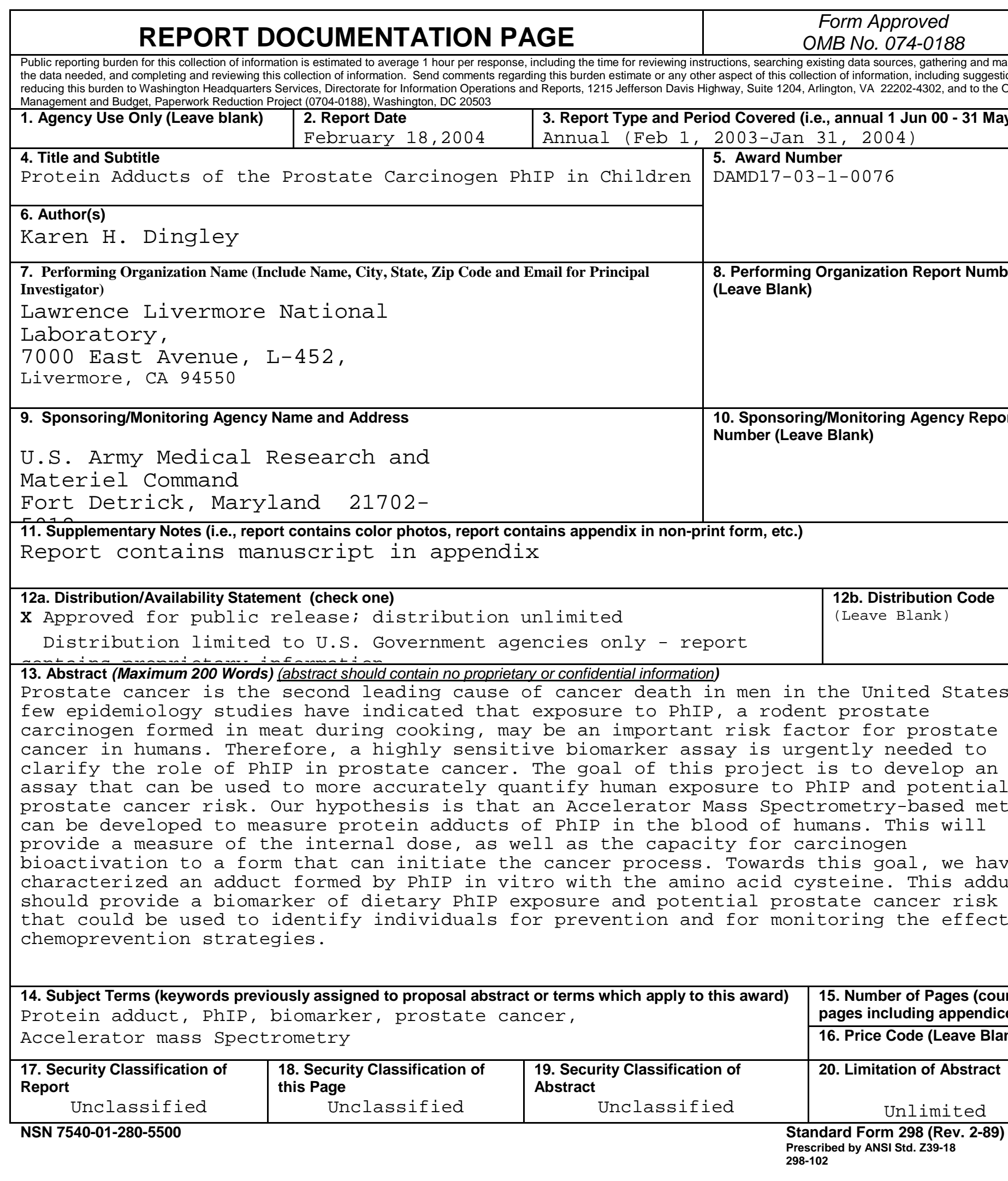




\section{Table of Contents}

Cover

SF 298

Table of contents

Introduction

Body

Key Research Accomplishments

Reportable Outcomes

Conclusions

References

Appendices
1

2

3

4

4

5

6

6

6

7 


\section{Introduction:}

Prostate cancer is the second leading cause of cancer death in men in the United States, with African-Americans having the highest rate of prostate cancer in the world. Despite these statistics, the specific causes and risk factors for prostate cancer and reasons for the racial disparity remain elusive. A few epidemiology studies have indicated that exposure to $\mathrm{PhIP}$, a rodent prostate carcinogen formed in meat during cooking, may be an important risk factor for prostate cancer in humans. There is also some evidence that African-American children have a 2-3 fold higher exposure to PhIP than White American children. Children are an important population to study because carcinogen exposure during development may lead to increased prostate cancer risk in later life. However, the epidemiology data are based upon PhIP exposure estimates from dietary questionnaires, rather than measurement of molecular markers that more accurately quantify an individual's internal dose and potential cancer risk. Therefore, a highly sensitive biomarker assay is urgently needed to clarify the role of PhIP in prostate cancer.

The goal of this project is to develop an assay that can be used to more accurately quantify human exposure to PhIP and potential prostate cancer risk. Our hypothesis is that an Accelerator Mass Spectrometry-based method can be developed to measure protein adducts of PhIP in the blood of humans. This will provide a measure of the internal dose, as well as the capacity for carcinogen bioactivation to a form that can initiate the cancer process. In a proof-of-principle study, we will use the assay to investigate the hypothesis that African-Americans may be at greater risk for prostate cancer than Whites because they have adduct levels that are 2-3 fold higher in childhood.

Our aims are to 1) Characterize the protein adducts formed by $\mathrm{PhIP}$ with the blood protein albumin. 2) Develop an ultrasensitive radiommunoassay for PhIP albumin adducts so that they can be assessed in populations of people. 3) Measure PhIP-albumin adduct levels in blood samples obtained from African-American and White male children.

\section{Body:}

During the first year of this grant (February 1, 2003 to January 31, 2004) we have made significant progress in specific aim 1 of the proposal. The progress is described as follows:

\section{Specific aim \#1: Characterize the adducts formed with the blood protein albumin after exposure to PhIP.}

The goal of this aim is to use in vitro methods to synthesize sufficient quantities of adducts for characterization by mass spectrometry and then establish if these adducts are formed in vivo in an animal model and humans.

Towards this goal, we have characterized a peptide adduct formed by the putative genotoxic metabolite, $N$-acetoxy-PhIP. A model peptide with the internal sequence LeuGln-Lys-Cys-Pro-Tyr, which is homologous to a potential target sequence for heterocyclic amines such as PhIP in human serum albumin, was reacted with $N$-acetoxy- 
$\mathrm{PhIP}$ and an adduct was identified and further characterized by LC-ESI MS/MS. $\mathrm{N}$ acetoxy-PhIP was covalently bound to the peptide via cysteine and the exocyclic amino group of PhIP. This work has been accepted for publication in Food and Chemical Toxicology (Chepanoske et al., see appendix for the manuscript).

The cysteine adduct was also formed when human serum albumin was reacted with $\mathrm{N}$ acetoxy PhIP, as previously described (Brown $e t a l$. 2001, and Chepanoske $e t a l$. In press). To remove non-covalently bound or unreacted $\mathrm{N}$-acetoxy $\mathrm{PhIP}$, the reacted samples were purified using affi-gel columns and then concentrated using MiliQ centricons. The albumin samples were then digested by trypsin and Glu-C to allow analysis by mass spectrometry. Samples were desalted using zip tips C18 and/or C18 Sep Pak cartridges upon injection into mass spectrometer. Data were collected on an ICR-FT mass spectrometer (Bruker, CA) operating in the positive mode. Each data set consisted of 400 experiments of 8-16 scans/experiment with a delay time of $0.5 \mathrm{sec}$. PhIP adducts seen in the Glu-C digest were confirmed in the tryptic digest and were all with cysteines on the surface of the protein.

Towards establishing if the adduct is formed in vivo, albumin was isolated from human and rat plasma samples using previously published methods (Dingley et al., 1998). We used a pooled plasma sample from rats that had been dosed with $\left[{ }^{14} \mathrm{C}\right] \mathrm{PhIP}$ at a dose of $90 \mu \mathrm{g} / \mathrm{kg}$ body-weight. The human sample was obtained from a previous study in which volunteers were administered $1 \mu \mathrm{g} / \mathrm{kg}$ body-weight $\left[{ }^{14} \mathrm{C}\right] \mathrm{PhIP}$ (Dingley et al., 1999). Heterocyclic amine adducts with a sulfur linkage to cysteine are cleaved by acid hydrolysis (Turesky et al., 1987). Hence by treating the albumin samples with acid, recovering PhIP through organic extraction and then analyzing using accelerator mass spectrometry, we can quantify the amount of the cysteine adduct formed in the rat and human plasma samples.

The acid hydrolysis method of Magagnotti et al. 2000 was used, with a few minor modifications. $500 \mu \mathrm{g}$ of rat albumin or up to $1 \mathrm{mg}$ of human albumin in $1-2 \mathrm{ml}$ buffer in $15 \mathrm{ml}$ glass tubes were acidified by adding $220 \mu \mathrm{l}$ of $1 \mathrm{~N} \mathrm{HCl}$, and hydrolyzed at $80^{\circ} \mathrm{C}$ for $1 \mathrm{hr}$. Immediately following the hydrolysis, the $\mathrm{pH}$ of the solution was made basic by adding $30 \mu \mathrm{l}$ of $10 \mathrm{~N} \mathrm{NaOH}$, and hydrolyzed PhIP was extracted three times with 1.5 times the sample volume of ethyl acetate. Extracted samples were dried by SpeedVac and analyzed by AMS. Preliminary data showed that $17 \%$ and $24 \%$ of the $\left[{ }^{14} \mathrm{C}\right] \mathrm{PhIP}$ in the rat and human samples, respectively, was recovered following acid hydrolysis. Therefore, this result implies that the cysteine adduct represents $17 \%$ of the total covalently bound $\mathrm{PhIP}$ in rats and $24 \%$ of the total covalently-bound PhIP in humans. This experiment will be repeated to verify the finding and to establish the variability between individuals.

\section{Key Research Accomplishments:}

During the first year of this grant, we have shown that:

- N-acetoxy PhIP, a bioactive form of the prostate carcinogen PhIP, forms a protein adduct with cysteine in a model peptide in vitro. This finding is being published in a peer-reviewed journal. 
- The cysteine adduct is also found in albumin that has been reacted with $\mathrm{N}$-acetoxy PhIP. The adducts form on the surface of the protein.

- Preliminary data indicates that the cysteine adduct is formed in vivo in rats and humans exposed to $\mathrm{PhIP}$.

\section{Reportable Outcomes:}

Publications

Cindy Lou Chepanoske, Karen Brown, Kenneth W. Turteltaub, and Karen H. Dingley. Characterization of a peptide adduct formed by $N$-acetoxy-2-amino-1-methyl-6phenylimidazo $[4,5-b]$ pyridine $(\mathrm{PhIP})$, a reactive intermediate of the food carcinogen PhIP. In Press, Food and Chemical Toxicology.

\section{Employment/Research Opportunities}

Over the period of this grant, we were able to hire a post-doctoral fellow (Anh-Tuyet Tran), a biomedical scientist (Sylvia Ahn) and a summer student, Kristin Stoker from UC Berkeley, to work on this project. This was the first opportunity for Ahn and Sylvia to work in prostate cancer research.

\section{Conclusions:}

During the first year of this grant, we have made significant progress towards our specific aims. We have shown that a reactive form of PhIP forms adducts with proteins in vitro and have characterized an adduct with cysteine. This adduct is formed with albumin in vitro and preliminary data indicates that it is also formed in vivo in rats and humans. We will now attempt to synthesize sufficient quantities of the adduct to raise antibodies. The antibodies will then be used in an immunoassay to quantify adduct levels in human blood samples.

\section{"So What?"}

As a result of the work completed over the past 1 year, we have established the structure of an albumin adduct formed by a prostate carcinogen in blood. This will be used to provide a biomarker of dietary PhIP exposure and potential prostate cancer risk that could be used to identify individuals for prevention and for monitoring the effect of chemoprevention strategies.

\section{References:}

Brown, K., Guenther, E.A., Dingley, K.H., Cosman, M., Harvey, C.A., Shields, S.J. and Turteltaub, K.W. (2001) Synthesis and spectroscopic characterization of site-specific 2amino-1-methyl-6-phenylimidazo[4,5-b]pyridine oligodeoxyribonucleotide adducts. Nucleic Acids Research, 29: 1951-1959.

Chepanoske, CL, Brown, K, Turteltaub, KW and Dingley, KH. Characterization of a peptide adduct formed by $N$-acetox $¥ 2$ - amino-1-methyl-6-phenylimidazo[4,5- $b]$ pyridine (PhIP), a reactive intermediate of the food carcinogen PhIP. In Press, Food and Chemical Toxicology. 
Dingley, KH, Freeman, SPHT, Nelson, DO, Garner, RC and Turteltaub, KW (1998) Covalent binding of 2-amino-3,8-dimethylimidazo[4,5-f]quinoxaline to albumin and hemoglobin at environmentally-relevant doses: a comparison of humans and the F344 rat. Drug Metabolism and Disposition, 26, 825-828.

Dingley, KH, Curtis, KD, Nowell, S, Felton, JS, Lang, NP and Turteltaub, KW (1999) DNA and protein adduct formation in the colon and blood of humans after exposure a dietary-relevant dose of 2-amino-1-methyl-6-phenylimidazo[4,5-b]pyridine. Cancer Epidemiology, Biomarkers and Prevention, 8, 507-512.

Magagnotti, C, Orsi, F, Bagnati, R, Celli, N, Rotilio, D, Fanelli, R, and Airoldi, L (2000) Effect of diet on serum albumin and hemoblobin adducts of 2-amino-1-methyl-6phenylimdazo[4,5-b] pyridine(PhIP) in humans. Int.J.Cancer: 88, 1-6.

Turesky RJ, Skipper PL, Tannenbaum SR. (1987) Binding of 2-amino-3methylimidazo[4,5-f]quinoline to hemoglobin and albumin in vivo in the rat. Identification of an adduct suitable for dosimetry. Carcinogenesis, 8(10):1537-42.

\section{Appendices:}

Copy of manuscript entitled:

Cindy Lou Chepanoske, Karen Brown, Kenneth W. Turteltaub, and Karen H. Dingley. Characterization of a peptide adduct formed by $\mathrm{N}$-acetoxy-2-amino-1-methyl-6phenylimidazo[4,5- $b$ ]pyridine (PhIP), a reactive intermediate of the food carcinogen PhIP. In Press, Food and Chemical Toxicology. 